Piśmiennictwo zakonne $w$ dobie staropolskiej, red. Magdalena Kuran, Katarzyna KaczorScheitler i Michał Kuran, przy współpracy Dawida Szymczaka, Łódź 2013.

Maria Wichowa ${ }^{1}$

Uniwersytet Łódzki

\title{
Dignitas humana $i$ humanitas christiana w poradniku medytacji Diega de Estella O wzgardzie świata i próżności jego w przekładzie Augustyna Kochańskiego (1611)
}

Termin humanitas przejęli intelektualiści renesansowi od autorów greckich i rzymskich, a w szczególności z pism Cycerona. W dziełach tego uczonego występuje on niemal synonimicznie z greckim słowem paideia, choć przy bliższym oglądzie idealnej zgodności znaczeniowej między nimi nie ma. Paideia była przede wszystkim określeniem helleńskiego wychowania, następnie ogólnego wykształcenia oferującego wartości tworzące wysoką kulturę i ogładę, wytworność manier, subtelność, szlachetność, otwarcie na drugiego człowieka. Pojęcie to „obejmuje całość kultury greckiej jako umysłowego i duchowego wytworu klasycznie ucywilizowanego społeczeństwa”"2. Cyceron natomiast pojmował humanitas ,jako synonim kultury i ogłady duchowej, bez której nie ma pełni człowieczeństwa”3.

Pisarz ten w dziele De officiis ( $O$ powinnościach) tłumaczył, że celem człowieka jest życie cnotliwe, prawe postępowanie ${ }^{4}$, kształtowanie swojej humanitatis. Jednak poszukiwanie prawdy o priorytetach moralnych nie może odwodzić od życia prak-

\footnotetext{
${ }^{1}$ Prof. dr hab. Maria Wichowa (ur. 1950) ukończyła studia polonistyczne na Uniwersytecie Łódzkim, na seminarium prof. J. Starnawskiego. Stopień naukowy doktora otrzymała w roku 1986 na podstawie dysertacji „Przeobrażenia” Jakuba Żebrowskiego i „Przemiany” Waleriana Otwinowskiego. Dwa staropolskie przekłady „Metamorfoz” Owidiusza. Promotorem był prof. Jerzy Starnawski. W roku 1998 opublikowała monografię Pisarstwo Jana Ostroroga (1565-1622), stanowiącą podstawę habilitacji. Tytuł profesora otrzymała w roku 2012 na podstawie monografii Dzieto Diega de Estella „O wzgardzie świata i próżności jego” $w$ przektadzie ks. Augustyna Kochańskiego jako poradnik medytacji: problemy komunikacji literackiej (2010).

Jest autorką sześciu książek, w tym 4 monografii, jednej edytorskiej ze wstępem monograficznym, jednej „rocznicowej” poświęconej Andrzejowi Fryczowi Modrzewskiemu oraz współautorką trzech kolejnych (2 tomów Antyk w Polsce i publikacji Pod cieniem Hippeum). Opublikowała łącznie około 140 artykułów naukowych.

${ }^{2}$ J. Budzyński, Paideia humanistyczna, czyli wychowanie do kultury. Studium z dziejów klasycznej edukacji w gimnazjach XVI-XVII wieku (na przykładzie Ślaska), Częstochowa 2003, s. 27; Ostatnio pisał na ten temat J. Koryl w pracy Humanitas septentrionalis - Christiana — Erasmiana, [w:] Humanizm. Historie pojęcia, red. A. Borowski, Warszawa 2009, s. 249-320. Godna najwyższej uwagi jest praca A. Nowickiej-Jeżowej, „Humanitas” w literaturze polskiego renesansu - ([w:] Humanitas. Projekty antropologii humanistycznej, cz. 1: Paradygmaty — Tradycje — Profile historyczne, red. A. Nowicka-Jeżowa, Warszawa 2009-2010).

${ }^{3}$ J. Budzyński, dz. cyt., s. 26.

${ }^{4}$ Cyceron, O powinnościach, [w:] tenże, Pisma filozoficzne, t. 2, przekł. W. Kornatowski, Warszawa 1960 (I, 18).
} 
tycznego, od aktywnej działalności w tym zakresie, bowiem wartość cnoty sprawdza się w działaniu. Arpinata tłumaczył synowi Markowi, któremu dedykował ten swoisty poradnik życiowy, jak ważne jest uznanie cnoty za dobro najwyższe. Cyceron opierał się na pismach stoików, ale na ich kanwie stworzył model etyki na własny użytek i potrzeby. Pisał:

Wszelkie zaś myślenie, wszelkie odruchy naszej świadomości będą dotyczyły już to powzięcia postanowień w zgodnych z cnotą, a związanych z dobrym i z szczęsnym życiem sprawach, już to poznawania prawdy i zdobywania wiedzy o niej5.

W cytowanym dziele zawarta jest konstatacja, że w naturze ludzkiej objawia się honestas — „zdolność dociekania prawdy, uczciwość społeczna, wielkość i wzniosłość umysłu”' C Człowiek posiada umiejętność rozróżniania dobra od zła, zatem powinien w swym postępowaniu obrać drogę cnoty. Podobnie rozumował Seneka pisząc, że w każdym człowieku posiane są ziarna dobra, które skłaniają go do cnotliwego postępowania ${ }^{7}$, są one pochodzenia boskiego (,semina in corporibus humanis divina dispersa sunt $\left.^{\prime \prime}\right)^{8}$. Poglądy te wykorzystał Kwintylian, budując swój wykład zasad pedagogicznych ( $O$ kształceniu mówcy). Humaniści renesansowi kładli nacisk na staranną erudycję klasyczną, głosili imperatyw formowania człowieka o szerokich zainteresowaniach (l’uomo universale), i kształtowania wybitnych indywidualności, wpajania i opanowywania uniwersalnej „sciencyi”. Celem takiego działania było „przyswojenie konkretnej wiedzy i opanowanie umiejętności w najlepszy sposób formujących, a następnie wyrażających człowieczeństwo uniwersalne" .

W dobie renesansu, w czasach, gdy starożytność klasyczna stanowiła obok Biblii najwyższy autorytet,

ideał tegoż doskonałego "człowieczeństwa« klasycznego był tak bogato i szeroko pojmowany, iż zawierano w nim z łatwością całe uniwersum kultury starożytnej. Pozwalało to nie tylko na przywracanie bezpośredniej więzi intelektualnej z dorobkiem umysłowym antyku, ale i na twórczy z nim dialog, i na takie nowoczesne modyfikacje, by można było jego dziedzictwo stosować w życiu obywatelskim i w polityce ${ }^{10}$.

Zatem humanitas to „szlachetność i wykwintność obyczajów, łaskawość, życzliwość, uprzejmość wobec innych, także erudycja, wysoki poziom kultury, znajomość jej osiągnięć w przeszłości, udział w tworzeniu jej w danej współczesności” ${ }^{11}$. Ludzkość wobec innych, najszlachetniejsze człowieczeństwo, miłość do człowieka - to kolejne aspekty cnoty zwanej humanitas. Dołożyć do tego należy troskę o formowanie indywidualności człowieka, jego osobowości kształtowanej w kategoriach „dobra i piękna", czyli postulat harmonijnego rozwoju człowieka cielesnego i człowieka duchowego

\footnotetext{
${ }^{5}$ M. T. Cyceron, O powinnościach, [w:] tenże, Pisma filozoficzne, ks. I, rozdz. 6, w. 19, s. 336.

${ }^{6}$ J. Koryl, dz. cyt., s. 269.

${ }^{7}$ Por. tamże, s. 269.

${ }^{8}$ L. A. Seneca, Ad Lucilium epistulae morales, London 1920, s. 112. (podaję za J. Koryl, dz. cyt.).

${ }^{9}$ J. Koryl, dz. cyt., s. 251.

${ }^{10}$ Tamże, s. 27.

${ }^{11}$ Cyt za: J. Pelc, Literatura renesansu w Polsce, Warszawa 1994, s. 10.
} 
(piękne ciało połączone z dobrocią i pięknem duchowym to cel pracy pedagogicznej). W poradniku Diega de Estella spolszczonym przez Augustyna Kochańskiego (1611) ${ }^{12}$, poświęconym medytacji „o wzgardzie świata i próżności jego”, niewątpliwie występuje dialog dwóch autorów renesansowych ze średniowieczną ideą de contemptu mundi i widoczna jest potrydencka, humanistyczna adaptacja tej idei. Średniowieczne antecedencje to: devotio moderna i nauka Tomasza z Kempis zawarta w dziele $O$ naśladowaniu Chrystusa, duchowość franciszkańska, doskonalenie się wewnętrzne człowieka przez ascezę („duchowy postępek”). Obaj pisarze franciszkańscy, autor oryginału (1524-1578) i jego polski tłumacz (1568-1632), prowadząc ów przyjazny dialog z nauką myślicieli poprzedniej epoki, dają jednak po części renesansową jej interpretację. Brat Diego postuluje odwrócenie się od światowych powabów, naucza „o marnym szczęściu świata tego”, o jego „próżnej a głupiej mądrości”, „o niebezpieczeństwie godności urzędów świeckich”, „o ślepocie ludzi światowych”, „o próżności rozkoszy świeckiej”, „o zapłacie, którą świat daje sługom swoim”. Jednocześnie trzeba zauważyć, że mimo ascetycznego charakteru zalecanych w poradniku tematów medytacji oraz średniowiecznej proweniencji głoszonej w niej idei, wyraźnie obecna jest renesansowa humanitas głosząca odrodzenie człowieczeństwa w Chrystusie (bumanitas Christiana). Postulowanie doskonalenia się przez ascezę, to nic innego jak ponowne narodziny duchowe człowieka ${ }^{13}$. W Ewangelii św. Jana Zbawiciel wyjaśnia: „zaprawdę, zaprawdę powiadam ci, jeśli się ktoś nie narodzi powtórnie, nie może ujrzeć królestwa Bożego", „[...] jeśli się ktoś nie narodzi z wody i z Ducha, nie może wejść do królestwa Bożego. To, co się z ciała narodziło jest ciałem, a to, co się z Ducha narodziło, jest duchem. Nie dziw się, że powiedziałem Ci: trzeba wam się powtórnie narodzič” (J. 3, 3-8). I dalej: „Albowiem Bóg nie posłał swojego syna na świat po to, aby świat potępił, ale po to, by świat został przez niego zbawiony" (J 3, 17). Człowiek odradza się przez chrzest ${ }^{14}$, który miał go zbawić jako stworzonego na obraz i podobieństwo Boże. „Zbawić — czyli zmienić i odrodzić istotę ludzką. Dzięki odrodzeniu przez chrzest człowiek z natury grzeszny, symbolicznie obmyty wodą chrztu, przeistaczał się w „nowe stworzenie”15. Paradoksalnie to nowe stworzenie podlega gloryfikacji w dziełach postulujących odwrócenie się od świata, powstałych w dobie pełnego renesansu, w pracach dwóch hiszpańskich teologów, oddziałujących na polskich katolików poprzez przekłady ${ }^{16}$.

Diego de Estella w swym nauczaniu sporo miejsca poświęca na rozważania o próżnej godności tego świata. Słowami Psalmu 138 ubolewa nad tym, że „nazbyt są uwiel-

\footnotetext{
${ }^{12}$ Wielebnego w Bodze Ojca i Brata, Dydaka Stellae, Hiszpana zakonu braci mniejszych Franciszka świętego, których de Observantia zową, O wzgardzie świata i próżności jego troje ksiag. Niedawno z hiszpańskiego języka na włoski, przez Hieremiusza Foreste, a włoskiego na łaciński od wielebnego w Bodze ojca, Piotra Burgunda, Societatis Jesu, z łacińskiego teraz zasię świeżo, przez brata Augustyna Kochańskiego, w Piśmie Świętym doktora, na ten czas kustosza gnieźnieńskiego, braci mniejszych Franciszka świętego Conventu nazwanych, pilnie przełożone. $\mathrm{Z}$ dozwoleniem starszych, w Poznaniu, w drukarnie Jana Wolraba, roku Pańskiego 1611.

${ }^{13}$ Por. J. Koryl, dz. cyt., s. 276.

${ }^{14}$ Por. W. Ullmann, Średniowieczne korzenie renesansowego humanizmu, przekł. J. Mach, Łódź 1985, s. 18-21.

${ }^{15}$ Tamże, s. 19.

${ }^{16}$ Por. P. O. Kristeller, Renesansowa koncepcja godności, przekł. E. Kubikowska, „Znak” 1997, nr 5, s. 21-36.
} 
bieni przyjaciele twoi, Boże, nazbyt wzmocniła się władza ich" ${ }^{17}$. Zabiegamy o własną cześć, ale tak naprawdę „próżność to jest szukać godności tej świeckiej, którą z wielką pracą dostaniemy, więcej dla niej utracamy a prędko ją opuszczamy” (cz. I, rozdz. 26, s. 72). Naprawdę to tylko „samym sługom Bożym własna przyzwoita jest cześć" (s. 72). Ci wszyscy, którzy teraz cieszą się szacunkiem, byli „sługami i przyjaciółmi Bożymi” (s. 73). Mowa oczywiście o Świętych Pańskich, odznaczali się właśnie tymi przymiotami. Zamiast zabiegać o własną pozycję, o wywyższenie, lepiej przyjąć postawę pokory, uznawać się za ziemię i popiół — doradza autor. Przy takiej postawie nie pragnie się próżnej i świeckiej godności, a mimo to dzięki pokorze można zostać nią obdarzonym. Jednak, jeśli chce się dostąpić godności wiekuistej, trzeba wystrzegać się tej doczesnej, bo jest ona „nikczemna i przemijająca” (s. 73). Człowiek, który tu na ziemi ,jest wzięty u ludzi a potężny”, powinien rozumieć, że w istocie „jest wielkim nędznikiem i grzesznikiem" (s. 73), chociaż wyniesionym ponad innych na tym świecie. Ozdobiony ziemskimi godnościami i bogactwami ma pamiętać, że są one „pożyczone” (s. 73), że po śmierci ich z sobą nie zabierze, lecz je odda światu. „Szczęśliwem ten jest nader, który pokornie naśladuje Chrystusa i pogardza próżną chwałą świata tego” (s. 73), gdyż dzięki temu dostąpi, „prawdziwej czci i godności niebieskiej” (s. 74). „Bogactwa tego świata nic nie są, jedno cień przeciwko prawdziwej rozkoszy niebieskiej” (s. 75). Człowiek obdarzony rozumem i rozsądkiem oraz godnością pochodzącą od Boga powinien odwrócić się od „tych nikczemnych marności” (s. 75). Hiszpański franciszkanin, przepojony myślą augustyńską, bardziej radykalnie ocenia wartość ziemskich dóbr niż uczony z Tagasty. W Wyznaniach nie ma bowiem nakazu odrzucenia świata, akcentowania jego marności, nacisk położony jest na przemijalność. Czytamy:

Bo cały ten ziemski ład, tak piękny, wszystkie te rzeczy bardzo dobre — gdy dojdą do kresu przeznaczonego dla ich istnienia - przeminą. Zaświtał niegdyś dla nich poranek, zapadnie nad nimi zmierzch ${ }^{18} .(13,35)$

W poradniku medytacji fray Diega uświadamia się człowiekowi, jak jest marny i grzeszny jako istota cielesna, ale zarazem docenia się jego godność. Właśnie wtedy, gdy mowa „o bogactwach tych doczesnych” (ks. I, rozdz. 19, s. 52) podkreśla się ową dignitas, która pochodzi od Boga.

O dziwna to rzecz, zaprawdę, będąc takim szlachetnym stworzeniem od Boga na chwałę jego uczynionym, że się w tak podłe rzeczy wdajesz i umysł Twój do tych marności przykładasz. (s. 53)

Godność człowieka objawia się w tym, że jest on obdarzony szlachetnością, bo stworzył go Bóg na swoją chwałę. Powinien więc swą aktywność skierować na miłość do rzeczy wielkich, znamienitych, czyli duchowych. Bóg przecież obdarzył szlachetnością człowieka „wnętrznego", stwarzając go na obraz i podobieństwo swoje. Przejawem godności jest miłość, pełna oddania, szlachetna i głęboka.

\footnotetext{
${ }^{17}$ W Biblii Wujka 138, 17: „A u mnie w wielkiej czci są przyjaciele Twoi, Boże, bardzo wzmocniło się ich panowanie".

${ }^{18}$ Św. Augustyn, Wyznania, przekł., wstęp i kalendarium Z. Kubiak, Kraków 2003, s. 423-424.
} 
Jako miłość przenosi miłującego w rzecz samę miłością zapaloną, iż więcej człowiek sam nie jest swym, a onej rzeczy miłującej. (ks. I, rozdz. 19, s. 53)

Miłość okazuje się utożsamiana z sercem, które jako ośrodek uczuć jest w człowieku cenne, wręcz nieoszacowane. Zatem nie można go poświęcać dla miłości dóbr materialnych, które są niczym innym, jak śmieciami i plugastwem. Mądrą, szlachetną miłość należy kierować ku tym darom, które otrzymaliśmy od Boga i ku samemu Stwórcy. Brat Kochański radzi:

Miłujże tedy Stworzyciela twego, nie żeć by też miał Pan Bóg tak dalece miłości potrzebować, ale chce, abyś go miłował na więtszy Twój pożytek i na cześć Twoją. Bo gdy się przemieniasz weń przez miłość, wiele zyskać możesz dając to, co dobrego jest, za tę rzecz, która zacności swej nigdy utracić zapłaty nie może.

Zatem najszlachetniejsza humanitas, najdoskonalsza postać godności człowieka objawia się w miłości do Boga, w boskości ludzkiej duszy. Człowiek obdarzony uniwersalnym umysłem, kierując się rozumem ma pełnię możliwości rozwoju swej humanitatis, a więc wznosić się ku Bogu, osiągać coraz wyższe stopnie wewnętrznej doskonałości, omijać niższe formy życia skażonego grzechem. Ksiądz Mateusz Ignacy Kuligowski, autor adaptacji dzieła ks. Besseusza Heraklita chrześcijańskiego albo grzesznika pokutującego lamenta (1694), tłumaczył, że „dusza Kościołem Ducha Świętego będąca staje się brzydką kloaką i fetorem” oraz traci godność. Tłumaczył tę kwestię następująco:

Lecz jeszcze tu nie koniec mojej niewdzięczności

Darów mych, którem dane miał do mej godności;

Którą gdy wspomnię godność, hojnie łzy lać muszę

Z oczu mych, bom obnażył z tej godności duszę.

Dusza ma, która w zacnym będąc dostojeństwie

Nieśmiertelności, miała żyć w błogosławieństwie

A współ Ducha Świętego przybytkiem być miała,

Tej godności i darom niegodna została,

A stała się szatana złego nierządnicą,

Grzechów i wszytkich diabłów strasznych niewolnicą ${ }^{19}$.

Zatem grzech niweczy godność człowieka, kala jego duszę. Podobnie rozumował hiszpański pisarz jezuicki Francisco Arias (1553-1605), teolog, autor dzieł o tematyce ascetycznej. W Traktacie o duchowym postępku ${ }^{20}$ tłumaczył ,jako jest przyjemny Panu Bogu człowiek postępek duchowny miłujący”. Otóż jest rzeczą pewną, że każdy człowiek sprawiedliwy, czyli obdarzony łaską Bożą, jest naturalnie Bogu miły. Natomiast nie każdy pobożny chrześcijanin podejmuje wysiłek nad doskonaleniem się

\footnotetext{
${ }^{19}$ Cyt. z: Heraklit chrześcijański ks. Piotra Besseusza z tacińskiego tekstu przez ks. Mateusza Ignacego Kuligowskiego, Stolice Apostolskiej protonotariusza, archidiakona bakkowieńskiego i plebana wolpińskiego wierszem polskim wyrażony, także z przydatkiem kunsztów poetyckich w różnych miejscach, to jest lament grzesznika pokutujacego..., Warszawa 1694, s. 22.

${ }^{20}$ F. Arias, Trzy traktaty duchowne, wprzód $z$ wtoskiego na taciński, a teraz z tacińskiego na polski nowo przetożone, przekł. ks. Wojciech Pakostensis Półgęskowic lub z grecka Mesochenius z Pakości, spowiednik od roku 1587 zakonnic klasztoru chełmińskiego, Poznań 1610, druk Jana Wolraba, egz. Bibl. IBL PAN, sygn. XVII.2.131.
} 
wewnętrznym, a to jest niezmiernie istotne dla zbawienia. Pożądane jest osiagnięcie stanu „duchowej żarzliwości”:

Abowiem kto nie wie, że tych, którzy z duchownej żarzliwości są pilnymi i co dzień w pobożności chcą mieć postępek i o to się z każdéj miary starają, aby wypełnieli, co Panu Bogu być wiedzą przyjemnego, więcej sobie waży Bóg i łaskawszy na nich jest niż na inszych wielu, choć sprawiedliwych, a o postępek duchowny nie barzo dbałych albo zabiegłych i to tylko upatrujących, aby jakim grzechem sprośnym Majestatu Boskiego nie obrażali ${ }^{21}$.

Pan Bóg wielu obdarzył łaską, ale bardziej kocha tych, którzy podjęli trud doskonalenia się wewnętrznego, od tych, którzy o to tylko dbają, aby wskutek grzechu śmiertelnego nie utracili tego daru, który mają. Człowiek pobożny obdarzony jest godnością dziecka Bożego, w modlitwie potrafi godnie wypowiedzieć „Boskich świadectw tajemnice”, a więc wyrazić, „w jakiej powadze jest u Boga człowiek okazały w cnocie, nieprzyjaciel grzechom, dobrych uczynków gorący miłośnik, cierpliwy w krzywdach, w miłości przeciwko bliźniemu i chwały Bożej pomnożeniu, żarzliwie"22. Homo meditans jest zaawansowany w zgłębianiu tajemnicy pobożności, dzięki temu, że jest świadomy Boskiej łaski i życzliwości. Rozumie, że skoro Stwórca ma go w takim poszanowaniu, „że go do uczestnictwa swego imienia przyjmuje, nazywając siebie Bogiem jego, i żeby go niczym nie zasmucił, królestwo całe dla niego przepuszcza" i prośbom staje się przychylny oraz zezwala, ,aby się w rzeczach stworzonych to działo”, co mu odpowiada. Człowiek z woli Bożej stał się panem i władcą przyrody, a wyróżnia go spośród innych stworzeń godność. Franciszek Arias sformułował bardzo precyzyjną definicję tego pojęcia:

To jest ona wielmożna moc, to jest ona czerstwość serca i wspaniałość, którą Bóg ćwiczącym się (W) prawdziwej pobożności wlewa, bo im przymnaża w rzeczach duchownych smaku, dobrego sumnienia, radości i wesela, w uciskach cierpliwości, w słowiech i przykładach skuteczności, miłości w poratowaniu bliźnich, przydaje im także niebieskich darów, a z łaską i miłością Bożą, okwity [zawiązków owocu. Przyp. - M.W.] znajomości tajemnic i darów bożych. Bowiem w służbie Bożej postępować człowieku sprawiedliwemu nic nie jest inszego, jedno darów i dobrodziejstw Boskich, z ręku Jego je wziąwszy, dobrze i godnie używać i za tak wielką dobroć jego a to miłosierdzie czymkolwiek nagradzać, aby tą wdzięcznością dać więcej nowych dobrodziejstw stać się godnym ${ }^{23}$.

Arias traktuje godność (dignitas) jako szczególną wartość osoby ludzkiej pozostającej w relacjach z Bogiem. Nadają one sens życiu i uzasadniają je w tym znaczeniu, że umożliwiają pozytywną ocenę własnej osoby. Ta ocena samego siebie, w wytworzeniu korzystnego obrazu jest oparta na solidnych postawach, mianowicie na wartościowych moralnie zachowaniach względem bliźnich i względem Boga, który hojnie je nagradza. Godność motywuje człowieka do postępowania zgodnego z obranym systemem wartości takich jak: pobożność, czyste sumienie, radość życia, miłość bliźniego, zabieganie o łaskę i miłość samego Stwórcy. Poczucie godności własnej, godności dziecka Bożego wymaga od człowieka postawionego w sytuacjach krytycznych poświadczenia w po-

\footnotetext{
${ }^{21}$ F. Arias, Traktat I: $O$ duchowym postępku, [w:] tenże, Trzy traktaty..., s. 1.

${ }^{22}$ Tamże, s. 16.

${ }^{23}$ Tamże, s. 28.
} 
stępowaniu posiadania owej cechy. Mianowicie trzeba szanować siebie nie odstępując od przyjętych zasad i szanować godność innych. Franciszek Arias, podobnie jak brat Diego, wyjaśnia, że potwierdzanie godności człowieka odbywa się na drodze duchowego postępku, czyli doskonalenia się wewnętrznego. A więc trzeba dobrze rozumieć, że Bóg jest majestatem i dobrocią nieskończoną, zatem słuszne jest, aby wszystkie jego stworzenia oddawały mu nieustającą cześć i chwałę. Jednak tej chwały i czci, jakiej on jest godzien, nie jesteśmy w stanie okazać mu w stopniu najwyższym,

bo natura nasza tego nie zniesie, żeby mogła mieć moc nieskończoną, tedyć pewnie sprawiedliwéj ,abyśmy według użyczonych sił od Boga, cokolwiek pokłonu chwały i posług uczynić możemy, jego majestatowi oddawali, i dlategoż samego każdego dnia na nowo o chwałę z przymnożenim wszystkich cnót się starali ${ }^{24}$.

Zatem godność pojmowana jest tu bardzo głęboko. Polega na nadprzyrodzonych relacjach człowieka z Bogiem, na całkowitym Mu zawierzeniu i podleganiu oraz na „dążeniu do wtopienia się w boską doskonałość i piękno"25, oddaniu się Bożej Opatrzności. Wyraża się w przekonaniu, że Bóg wszechmocny czyni człowieka mądrym i dobrym, pomaga mu zbliżyć się do świętości, pracować nad doskonaleniem wewnętrznym. Homo liber musi dokonywać przy pomocy rozumu właściwych wyborów życiowych w oparciu o aksjologię chrześcijańską, wyzbywać się wad, dostrzegać doskonałość Stwórcy i chwalić Go. Oczywiście człowiek wolny, wolny w Bogu, zna swoją tożsamość i wartość swoją jako osoby. Humanitas Christiana opierała się na koncepcji, że w świecie panuje porządek nadprzyrodzony, w którym głównym elementem jest łaska oraz porządek naturalny. Badacz relacji humanizmu i chrześcijaństwa pisał o tym następująco:

„Nadprzyrodzony” oznaczało ten specjalny dar przyniesiony przez Chrystusa, że przez Niego z Nim i w Nim zwykli ludzie mogą wejść w nowe związki z Bogiem. Przez ten związek ludzie mogą stać się współdziedzicami z Chrystusem, synami Boga w sensie, w jakim sam Chrystus był synem Boga. Krótko mówiąc człowiek może osiągnąc stan boskości zachowując przy tym swoją ludzką osobowość. Przez porządek naturalny rozumiano wszystko, co człowiek potrafi zrobić, wymyślić, a także czym może się stać dzięki własnym wysiłkom ${ }^{26}$.

Jak widać, ludzka godność polega także na wolności wyboru wartości. Istnieją przecież rozmaite propozycje i możliwości, w tym wartości najwyższe. Jeśli człowiek wybiera to, co najcenniejsze, a zarazem to, co wywodzi się z doświadczenia ludzkich osiągnięć, a zatem to, co jest piękne i moralnie dobre, to w ten sposób zaświadcza swoją godność. Jego sumienie posiada świadomość tego, co musi być bezwzględnie wypełnione i tego, co jest całkowicie zakazane i niedopuszczalne. W tak budowanej skali wartości pierwsze miejsce zajmuje miłość — podstawa dignitatis humanae w ujęciu chrześcijańskim. Pisał o tym jezuicki teolog Franciszek Arias, podając bardzo wnikliwą formułę miłości, obowiązującą w relacjach miedzy Bogiem a człowiekiem:

\footnotetext{
${ }^{24}$ Tamże, s. 40 .

${ }^{25}$ Cyt. za: M. C. D’Arcy, Humanizm i chrzéscijaństwo, przekł. W. Grochulski, Warszawa 1973, s. 46.

${ }^{26}$ Tamże, s. 52.
} 
Miłość, którą w nas Bóg miłuje, i od wieków miłował, końca nie ma, bo ta miłość jest sama istność Boska. Rozum tedy sam uczy, abyśmy nieskończonej miłości Jemu oddać nie mogąc, przynamniéj miłości pewnymi granicami nie określali, ale co dzień przez ćwiczenie w sobie modlitwy i inszych uczynków dobrych przestronną czynili, i jakoby węglem żarzystym przyczyniali, od którego się miłości ogień silić i rozszerzać zwykł. Nadto, iż dobrodziejstwa z tej nieskończonej miłości pochodzą, a są w swej wielkości nieskończone i rozlicznością niezliczone, a mianowicie dobrodziejstwo naszego odkupienia, które w sobie wszystkie Pana Chrystusowe dzieje, wszystkie słowa wymówione, wszystkie uciski bolesne wytrwamy, wszystkie na koniec łaski i dary duchowne zawiera $[\ldots]^{27}$.

Skoro Pan Bóg „doskonale jest baczny i mądry” ${ }^{28}$, ludzie nie powinni się dziwić, że mając wokół siebie licznych „sług”, jednych bardziej, drugich mniej kocha, a należy to tłumaczyć tym, że nie każdy chrześcijanin w jednakowym stopniu angażuje się w pogłębianie doskonałości. Otóż, część ludzi to tacy, „którzy są w łasce u Pana Boga, ale o postępku duchownym nic się nie pytając ani oń dbając, tego tylko strzegą, aby przez grzech śmiertelny tej łaski, którą mają, nie stracili [...]" ${ }^{29}$. Ci zachowują status quo, nie pracują nad tym, aby stali się jeszcze lepszymi, stąd łaski i miłości Bożej mają mniej.

Uczony jezuicki bardzo głęboko i wnikliwie analizuje tajemnicę pobożności. Wyraźnie ją łączy z godnością człowieka.

A kto może godnie wyrazić tych Boskich świadectw tajemnicę, to jest w jakiej powadze jest u Boga człowiek okazały w cnocie, nieprzyjaciel grzechom, dobrych uczynków gorący miłośnik, cierpliwy w krzywdach, w miłości przeciwko [do. Przyp. - M.W.] bliźniemu i chwały Bożej pomnożeniu, żarzliwy. Albowiem w takim go ma poszanowaniu, że go do uczestnictwa swego imienia przyjmuje, nazywając siebie Bogiem jego, iżeby go niczym nie zasmucił, królestwu całemu dla niego przepuszcza i prośbami jego dawszy się zniewolić, przyrodzonemu się prawu zniża, że dopuszcza, aby się w rzeczach stworzonych to działo, co się jemu podoba. Na koniec, dla niego samego czyni, czego by dla wielu inszych sprawiedliwych, którzy mu niedoskonale służą, nie uczynił, a choć Bóg jest wieczny i nieskończony Majestat, a człowiek stworzeniem z niczego uczynionym, przecie dlatego, aby wolej człowieka dogodził, czyni się równym stworzeniu, gdy mówi: „Obronię miasto to dla mnie i dla Dawida, sługi mego”"30.

Cytat biblijny jest przytoczony nieco niedokładnie. Pismo Święte podaje, że Jahwe rozgniewał się na Salomona, który czcił obcych bogów, nie zachował przymierza ze swym Bogiem i jego praw. Zapowiedział, że pozbawi Salomona królestwa i odda je jego słudze ${ }^{31}$. Arias, zgodnie z praktyką pisarską swoich czasów, przytaczał Biblię tak, aby zachować sens wypowiedzi, ale nie uważał za niestosowną lekkiej modyfikacji tekstu w taki sposób, żeby przywołany werset idealnie przystawał do myśli przewodniej dzieła, w którym je umieszczono.

Ten szeroki kontekst duchowości chrześcijańskiej, od św. Augustyna poprzez Tomasza z Kempis, Ignacego Loyolę ${ }^{32}$ aż po Diega de Estella uwzględnił tłumacz jego

\footnotetext{
${ }^{27}$ F. Arias, dz. cyt., s. 41-42.

${ }^{28}$ Tamże, s. 3.

${ }^{29}$ Tamże, s. 3.

${ }^{30}$ Tamże, s. 4.

${ }^{31} 1 \mathrm{Krl}$ 11,12-13: „Choć nie uczynię tego za twego życia ze względu na twego ojca Dawida, to wyrwę je z ręki twego syna. Jednak nie wyrwę całego królestwa. Dam twojemu synowi jedno pokolenie ze względu na Dawida, mego sługę i ze względu na Jeruzalem, które wybrałem”.

32 Por. A. Poprawa-Kaczyńska, Ignacjański „modus meditandi” w kulturze religijnej późnego baroku. Rekonesans, [w:] Religijność literatury polskiego baroku, red. Cz. Hernas, M. Hanusiewicz, Lublin 1995, s. $259-270$.
} 
traktatu, polski franciszkanin, Augustyn Kochański, jednakże dość surowo obchodząc się z powabami świata doczesnego, nędznego i przemijającego, który radykalnie przeciwstawia niebu. Pisał o tym w Przedmowie do przekładu:

Bo wejrzawszy na samo tak piękne sklepienie niebieskie, pomyśliwszy sobie na ono światło, nigdy rozumem ludzkiem nie pojęte Boga samego, uważywszy rozkoszy, których z widzenia jego święci wiekuiście zażywają, kto by, proszę, był tak twardy, aby się raczej z tego świata, tak nędznego i przemijającego, do onego wiekuistego a nieskończonego mieszkania spieszyć nie chciał? (Przedmowa, s. 1)

Przejawia się w tym cytacie poruszana przez św. Augustyna kwestia relacji między wiarą i rozumem. Wiara nie odrzuca ani nie kwestionuje sądów rozumu. Są jednak pewne zagadnienia w nauce Kościoła, w których wiara wyprzedza rozum. „Zresztą rozum się wówczas tego domaga, aby wiara oczyszczała serce tak, by człowiek mógł uchwycić i znieść światło tego, który jest Wielkim Rozumem”33. Kochański, jak się wydaje, deprecjonuje nieco możliwości poznawcze rozumu. Nie drąży zbytnio tego tematu, jednak w podtekście jego rozważań pojawia się augustyński nakaz: „Uwierz, abyś zrozumiał” i jego odwrotność: „zrozum, abyś uwierzył”. Te dwa sposoby poznania nie wykluczają się, raczej uzupełniają się wzajemnie. Brat Augustyn wydaje się skłaniać ku koncepcji, że rozum jest dobrym narzędziem poznania, ale nie wystarczy do ogarnięcia Boga. Wiara natomiast pomaga w zrozumieniu siebie i świata, poszerza i pogłębia zdobytą na drodze rozumowej wiedzę. Widać przy tym, że tłumacz uznaje prymat woli i uczucia nad rozumem. Przytoczony fragment Przedmowy zwraca uwagę na jeszcze jeden aspekt nędznej ludzkiej kondycji, mianowicie mowa jest o tym, że ziemska egzystencja człowieka to $\mathrm{w}$ istocie peregrinatio ad Deum, zatem nakłania tłumacz do porzucenia świata doczesnego, aby tym prędzej znaleźć się w ojczyźnie niebieskiej. Zaleca więc pielgrzymowi rozważania $O$ zamknieniu bran mitości świata tego przed Bogiem (ks. II, rozdz. 21, s. 157).

Wielkie są głosy i krzyki w uszu tych, którzy się przyłączają światu temu; pragnienia godności nie ustają od wołania, zatym nie dziw, że pełnym i obciążonym, które się nigdy nasycić nie mogą, wedle powieści onego Owidyjusza: im więcej kto pije wody, tym pragnienia więtsze z wody.

Odwołał się do mitu o Narcyzie, który „pije i pijąc widzi piękne oblicze, kocha coś, co nie ma ciała, lub raczej uważa za ciało coś, co jest wodą" ${ }^{4}$. Zdanie „pragnienia godności nie ustają od wołania” zawiera krytykę tych, którzy wysoko stawiają dignitas humanae; upominanie się o tę wartość jest zakrzykiwaniem głosu Boga. Kochański prezentuje postawę konserwatywną, piętnuje nieustające wołanie ludzi świeckich o godność, zatem jest zwolennikiem starego porządku, czyli idei contemptus mundi. Dlatego nie „nowoczesny” postulat autokreacji przez bone litterae, lecz uznanie swej marności zaleca jako temat medytacji. Na marginesie odwołał się do Psalmu 10

\footnotetext{
${ }^{33}$ J. Salij OP, Rozmowy ze świętym Augustynem, Poznań 1997, s. 110.

${ }_{34}$ Owidiusz, Metamorfozy, przeł. A. Kamieńska, St. Stabryła, oprac. St. Stabryła, Wrocław 1995, (ks. III, s. 77).
} 
(według Wulgaty 9), w. 3: „Bo występny chełpi się swym pożądaniem, bluźni drapieżca i pogardza Jahwe”. Zatem w życiu codziennym postępuje tak, jakby Boga nie było. Augustyn Kochański przekonuje, że pogrążanie się człowieka w codzienności, w realiach świata ziemskiego, odciąga go od Boga, wzbudza „nietrwałą miłość rzeczy świata tego" (Sęp). Dignitas swą człowiek może potwierdzić w modlitwie. Jest ona wyrazem godności ludzkiej istoty, jest także użytecznym narzędziem doskonalenia się, najszlachetniejszym drgnieniem pokornego serca ludzkiego.

Autor pierwszego w dobie potrydenckiej modlitewnika Harfa duchowna, jezuita Marcin Laterna ${ }^{35}$, mocno ten fakt eksponował. „Modlitwa upokarzającego się człowieka przenika niebiosa” (s. 13), jest drogą do chrześcijańskiej doskonałości, a ma być wznoszona w stanie czystości serca, „Aby oko - twoja dusza, bielmem jakim nieszczerości z Panem Bogiem nie zachodziło" (s. 13). Wówczas człowiek ma poczucie swojej godności, ma prawo zwracać się w pokorze do serca Boskiego. Dusza ludzka garnie się do samego Boga jako pewnego kresu i końca ostatniego i pragnie Go, zatem wartościami życia codziennego, doczesnymi przyjemnościami nie może się zaspokoić. Brat Kochański konstruuje wywód na ten temat w duchu augustyńskim, posługując się nawet kryptocytatem z Wyznañ: „Uczynił nas Pan Bóg dla siebie i dał niespokojne serce nasze, ażeby się ku niemu nawróciło" ${ }^{36}$. Jak wiadomo, metafora serca występuje już w Biblii (1 Krl 9, 4). Jakub zwracał się do Salomona, który ukończył budowę świątyni, następującymi słowami:

Ty zaś, jeżeli będziesz postępował wobec Mnie, jak postępował twój ojciec Dawid, w szczerości serca i w uczciwości, wypełniając wszystko, do czego cię zobowiązałem, jeżeli będziesz strzegł moich praw i nakazów, to na wieki utrwalę tron twego królowania nad Izraelem [...].

Zatem Dawid pozostawał w doskonałości serca. Identyczną wykładnię tej przenośni daje biskup Hippony. Współczesny badacz ujął to syntetycznie:

U Augustyna i w tradycji ludzkości, serce oznacza, mówiąc ściślej, niepowtarzalne, osobowe centrum człowieka, w którym wszystkie jego moce mają swoje źródło i do samej głębi wzajemnie się przenikają. Powrót do najbardziej własnej jaźni nie jest więc skierowany jedynie do sfery myśli czy woli, czy uczucia; chodzi tu raczej o dotarcie do tego rdzenia, w którym zarówno wymienione właśnie, jak i wszystkie inne ludzkie moce stanowią jeszcze zupełną jednośśc ${ }^{37}$.

W użyciu potocznym metafora serca oznacza miłość, szczególnie miłość niebiańską, dobroć, szlachetność, źródło życia i uczuć. W języku teologii oznacza głęboką mądrość, rozum. W pismach religijnych serce jest synonimem źródła prawdy, organem

\footnotetext{
${ }^{35}$ M. Laterna, Harfa duchowna, to jest dziesięć rozdziatów modlitw katolickich. Wydano do każdego rozdziatu nauki o tych rzeczach, które się $w$ modlitwach zamykaja, a na niektórych miejscach wykłady i przypisami psalmy i modlitwy objaśniono, Kraków 1612 (I wyd. Kraków 1585), cytaty pochodzą z przedmowy do edycji z 1612 roku.

36 Św. Augustyn, Wyznania, przekł. Z. Kubiak, Kraków 2003, s. 25: „Stworzyłeś nas bowiem jako skierowanych ku Tobie, i niespokojne jest serce nasze, dopóki w Tobie nie spocznie”. Por. Wł. Kopaliński, Stownik symboli, Warszawa 1990 (h. serce, s. 1175).

${ }^{37}$ J. B. Lotz, Wdrożenie w medytację nad „Nowym Testamentem”, Kraków 1985, s. 27.
} 
kontemplacji i posiadającym zdolność odczytywania, przenikania świata wartości, ośrodkiem życia duchowego, co zawarte jest w modlitewnym zwrocie sursum corda. Przez serce rozumiemy „szczytową zdolność osoby ludzkiej do identyfikowania świata wartości, do uznawania tych wartości i pozostawania z nimi w jedności, w komunii. U źródeł i szczytu wszystkich wartości jest Bóg. Dlatego tak trafne i doniosłe jest stwierdzenie św. Augustyna: „Redeamus ad cor et inveniamus Eum - udajmy się do serca, a znajdziemy Go (Wyznania, IV, 12)"38, potwierdzimy swoją godność.

Autor polskiej adaptacji poradnika medytacji $O$ wzgardzie świata... zwraca uwagę na dziwną cechę ludzkiej natury. Stwierdza mianowicie, że wszystkie stworzenia robią to, do czego zostały stworzone, tylko jedynie człowiek ,jest tak krnąbrnym, iż nie chce ani pragnie dostąpić końca swego" (297). Lgnie on mianowicie od spraw ziemskich, a Pan Bóg stworzył go dla nieba. Tymczasem człowiek powinien rozumieć, że musi dążyć do tego, aby swój kres pokładał tylko w Bogu. Uczony z Tagasty wyjaśniał, że jeśli człowiek odczuwa radość z posiadania rzeczy materialnych, to powinien za to okazywać wdzięczność Bogu i chwalić Go. Miłość swą ma skierować nie ku nim, lecz ku ich Stwórcy, inaczej posiadacz tych dóbr przestanie podobać się Jemu.

Od Niego pochodząc, te rzeczy w Nim istnieją. On jest wszędzie tam, gdzie odczuwamy smak prawdy. Przebywa w samej głębinie naszego serca, a serce odeszło od Niego, by błądzić po manowcach. „Wróćcie występni, do serca" - uchwyćcie się Tego, który stworzył was! Spocznijcie w Nim, a będziecie mieli pokój. [...] To dobro, które kochacie, od Niego pochodzi. Tylko w takiej mierze jest dobrem i czymś drogim, w jakiej jest skierowane ku Niemu. Słusznie przemieni się w gorycz, jeśli człowiek opuszcza Boga i nieprawą miłością kocha to, co od Niego pochodzi ${ }^{39}$.

Posiadanie dóbr doczesnych nie uszczęśliwi człowieka. Chciwość, pożądanie rzeczy materialnych obraca się przeciwko ludziom o nieczystym sercu, w którym nie ma Boga, tylko miłość do posiadanego majątku, często zresztą będącego rezultatem niesprawiedliwości w relacjach miedzy ludźmi. Stają się oni z powodu bogactwa próżni i zarozumiali. „Chełpią się tak, jakby nie otrzymali” (1 Kor 4, 7). Są bogaci według swojej miary, ubodzy według miary Boga.

Kontynuując naukę biskupa Hippony brat Augustyn Kochański wyjaśnia, że drogą doskonalenia się wewnętrznego chrześcijanina jest miłość, idzie jednak o krok dalej w nakazie całkowitego odrzucenia świata.

Boga samego miełuj, od którego i dla któregoś jest stworzony. Wzgardź tym światem mizernym, a dostąpisz kresu pożądanego. I miałbyś zaiste na tej samej przyczynie tak poważnej przestać i pogardzić próżnością tego świata? Pamiętaj na to, żeś stworzony do niebieskiej rzeczy, za tak marnymi rzeczoma nie udawaj się. Co gdy tak uczynisz, w pokoju na świecie żyć i w niebie na wieki błogosławionym i wielbionym będziesz. (s. 298-299)

Jak widać, jest to reinterpretacja myśli świętego Augustyna, zawierająca nakaz gardzenia światem. W przytoczonym zakończeniu rozdziału XXXVII cz. 3 tłumaczącego Do którego końca jest człowiek stworzony, w pełni doszła do głosu duchowość franciszkańska.

\footnotetext{
${ }^{38}$ Podaję za: W. Słomka, Medytuję, więc jestem, Łódź 1992, s. 45.

${ }^{39}$ Św. Augustyn, Wyznania..., IV, 12, s. 99-100.
} 
Autor dobrze rozumie, że świat ludzkich wartości jest bardzo bogaty, podobnie jak świat uczuć, ściśle z nim związany. Człowiek dokonuje nieustannych wyborów: coś akceptuje, czegoś pragnie, czegoś się boi, czegoś oczekuje, kogoś kocha, kogoś nie lubi, zatem choć generalnie wybrał preferowane przez siebie wartości, to jednak bezustannie dokonuje doraźnych wyborów. Jest to ważne szczególnie w poradniku medytacji, który cały jest nastawiony na propagowanie wskazanej w tytule idei, ma na celu przekonanie do niej jak największej liczby osób, oferując odbiorcom pełną, wnikliwą analizę tego "dobra”, jakim jest odwrócenie się od świata i pogrążenie w medytacji, zbliżenie się do Boga, wydobycie z siebie dobroci. Późnośredniowieczny filozof, mistyk Mistrz Eckhart zwrócił uwagę na bardzo ważny aspekt obecności w życiu człowieka tej wartości:

Dobroć nie jest stworzona, uczyniona ani zrodzona, jest natomiast rodząca i rodzi dobrego, on zaś jako taki nie jest stworzony ani uczyniony, lecz jest zrodzonym dzieckiem i czynem dobroci ${ }^{40}$.

Dobry człowiek, a ujmując rzecz na wyższym stopniu uogólnienia, osoba ludzka, jest uwikłana w relacje dialogiczne, które mają charakter podmiotowy. „Osoba pojawia się na świecie z głębi uczestnictwa. Uczestnictwo jest zapytywaniem, wybieraniem, uznaniem w dobru, ustanowieniem "nieprzedmiotowej « wspólnoty”¹. To uczestnictwo oznacza m.in. przyjmowanie i przekazywanie wartości. W proces ten silnie są zaangażowani autor i odbiorcy poradnika $O$ wzgardzie świata, zalecającego postępowanie według preferowanych wartości, które są , wiecznym źródłem fascynacji dla ludzkiego życia i myślenia” ${ }^{42}$. Augustyn Kochański postawił pytanie, które po czterech stuleciach zadał ponownie współczesny uczony, również duchowny, jednak nie doktor teologii, lecz profesor filozofii, Józef Tischner, mianowicie: ,jakie doświadczenie jest dla nas podstawowym źródłem wszystkich przeżyć aksjologicznych z przeżyciem myślenia włącznie?” ${ }^{43}$ Odpowiedź obu intelektualistów jest identyczna. Kochański dostrzegał, że „zwierciadło człowieka jest drugi człowiek” (ks. III, rozdz. 13, s. 236), tłumacząc, iż to proch, pył, ziemska marność, a więc stosował wartościowanie ujemne, zgodne z naczelną ideą poradnika. Dla Tischnera takim doświadczeniem także jest spotkanie z drugim człowiekiem. „Doświadczenie spotkania kryje w sobie niezwykłą siłę perswazji. Spotkanie jest czymś więcej niż »zetknięciem się» z drugim, widzeniem, czy słyszeniem drugiego. Od spotkania zaczyna się dramat, którego przebiegu nie da się przewidzieć”ł ${ }^{4}$. Niemały udział w tych dramatycznych spotkaniach człowieka z człowiekiem owocujących przemianami uczestników wynikającymi z wzajemnego oddziaływania na nich systemu wartości, a więc ich postawy wobec dobra i zła itd. Spotkanie w ten

\footnotetext{
${ }^{40}$ Cyt. za: Mistrz Eckhart, Księga Boskich pocieszeń, [w:] tenże, Traktaty, przekł. W. Szymona OP, Poznań 1987, s. 81-82. Pisał o tym J. Tischner w pracy: Spór o istnienie człowieka, Kraków 1998, przedr. fragm. [w:] tenże, O człowieku. Wybór pism filozoficznych, wyb. i oprac. A. Bobko, Wrocław 2003/2006, BN I 306.

${ }^{41} \mathrm{~J}$. Tischner, $d z$. cyt., s. 421.

${ }^{42}$ Tenże, Myślenie wedtug wartości, s. 242.

${ }^{43}$ Tamże, s. 242.

${ }^{44}$ Tamże, s. 242-243.
} 
sposób rozumiane „skłania [...] nie tylko do preferencyjnego czucia, lecz również do preferencyjnego myślenia. Aksjologia wyrasta z samego rdzenia tego, kim jesteśmy”“45. W czasach powszechnego nawoływania przez Kościół do wzgardy światem, do rozmyślań nad jego próżnością, nad marnością człowieka, intelektualiści czasów renesansu i doby baroku włożyli wiele wysiłku w budowę teorii godności ludzkiej i humanitatis, głoszącej odrodzenie człowieka w Chrystusie. Jest on obdarzony rozumem i rozsądkiem oraz godnością pochodzącą od Boga, powinien odwrócić się od marności światowych i podążać drogą naśladowania Chrystusa.

\section{Dignitas Humana and Humanitas Christiana in Diego de Estella's Meditation Guide $O$ wzgardzie świata i próżności jego translated by Augustyn Kochański (1611)}

\section{Summary}

The subject of study is human dignity and humanitas christiana interpreted by a Spanish Franciscan Diego de Estella (1524-1578) in his work O wzgardzie świata i próżności jego translated into Polish by another Franciscian Augustyn Kochański (1568-1632). The book is a meditation guide. In spite of the ascetic character of the recommended meditations and Medieval origin of their central idea being de contemptu mundi, the image of the world presented in the book conveys the Renaissance humanitas propagating the rebirth of the humanity through Jesus Christ (humanitas christiana). Spiritual rebirth of a human being is hereby identified with improving oneself by means of asceticism. The most noble humanitas and the most perfect form of human dignity is revealed through love for God, through the divine element within the human soul. A human having been given a universal mind is capable of fully developing his or her humanitas, in this way establishing union with God, achieving spiritual perfection and eluding inferior forms of life infected by sin.

The analysis is made within a relatively broad comparative context. It includes Mateusz Kuligowski's translation of the work by M. P. Besse Heraklita chrześcijańskiego albo grzesznie pokutujacego lamenta (1694); Wojciech Pakostensis Półgęskowic's translation of a Spanish Jesuit and teologist Francisco Arias' work entitled Traktat o duchowym postępku (1610); St. Augustine's Confessions, as well as Thomas à Kempis' The Imitation of Christ. The study proves that in the times when the Church stressed the futility of life and scorned the vanities of the world, the intellectuals of Renaissance and Baroque put a lot of effort in creating the theory of human dignity and humanitatis by propagating the idea of human rebirth through Christ. Humans having been bestowed with reason and dignity coming from God should turn away from the world's vanities and follow the imitationis Christi way.

\footnotetext{
${ }^{45}$ Tamże, s. 243.
} 